\title{
Clinical utility gene card for: malignant hyperthermia
}

\author{
Henry Rosenberg ${ }^{\star, 1}$ and Henrik Rueffert ${ }^{2,3}$ \\ European Journal of Human Genetics (2011) 19, doi:10.1038/ejhg.2010.248; published online 19 January 2011
}

\section{DISEASE CHARACTERISTICS}

1.1 Name of the disease (synonyms)

Malignant hyperthermia (MH)., ${ }^{1,2}$

1.2 OMIM\# of the disease

145600.

1.3 Name of the analyzed genes or DNA/chromosome segments RYR1 (chr.19q13.1), CACNA1S (chr. 1q3). ${ }^{3,4}$

1.4 OMIM\# of the gene(s)

180901 (RYR1), 114208 (CACNA1S).

1.5 Mutational spectrum

30 functionally confirmed causative point mutations ( $R Y R 1$ ), about $200 \mathrm{MH}$-associated mutations in RYR1, few mutations in CACNA1S (of minor importance). ${ }^{5-8}$

1.6 Analytical methods

Sequence analysis of the entire coding region (RYR1: $16000 \mathrm{bp}$ ); sequence analysis of selected exons, mutation scanning of the entire coding region, mutation scanning of selected exons (direct sequencing, DHPLC, MLPA, restriction enzyme analysis). ${ }^{9-13}$

\subsection{Analytical validation}

$>95 \%$ specificity, depending on the correctness of the phenotype.

1.8 Estimated frequency of the disease

(incidence at birth ('birth prevalence') or population prevalence) Genetic incidence: 1:3000-1:10 000. ${ }^{14}$

Clinical prevalence: 1:60 000-1:100 000.15,16

1.9 If applicable, prevalence in the ethnic group of investigated person

Not applicable.

\subsection{Diagnostic setting}

\begin{tabular}{lll}
\hline & Yes & No \\
A. (Differential) diagnostics & $\bigotimes$ & $\square$ \\
B. Predictive testing & $\bigotimes$ & $\square$ \\
C. Risk assessment in relatives & $\bigotimes$ & $\square$ \\
D. Prenatal & $\bigotimes$ & $\square$ \\
\hline
\end{tabular}

Comment D:

Meaningful but not yet approved.

\section{TEST CHARACTERISTICS}

\begin{tabular}{|c|c|c|c|c|}
\hline & \multicolumn{2}{|c|}{ Genotype or disease } & \multirow{2}{*}{$\begin{array}{l}\text { A: True positives } \\
\text { B: False positives }\end{array}$} & \multirow{2}{*}{$\begin{array}{l}\text { C: False negative } \\
\text { D: True negative }\end{array}$} \\
\hline & Present & Absent & & \\
\hline \multicolumn{5}{|l|}{ Test } \\
\hline \multirow[t]{2}{*}{ Positive } & A & B & Sensitivity: & $A /(A+C)$ \\
\hline & & & Specificity: & $D /(D+B)$ \\
\hline \multirow[t]{2}{*}{ Negative } & C & $\mathrm{D}$ & Positive predictive value: & $A /(A+B)$ \\
\hline & & & Negative predictive value: & $\mathrm{D} /(\mathrm{C}+\mathrm{D})$ \\
\hline
\end{tabular}

\subsection{Analytical sensitivity}

(proportion of positive tests if the genotype is present)

$100 \%$.

\subsection{Analytical specificity}

(proportion of negative tests if the genotype is not present) $100 \%$.

2.3 Clinical sensitivity

(proportion of positive tests if the genotype is present) (20,21 $^{2}$ $>70 \%$.

\subsection{Clinical specificity}

(proportion of negative tests if the disease is not present) ${ }^{20,21}$

The clinical specificity can be dependent on variable factors, such as age or family history. In such cases, a general statement should be given, even if a quantification can only be made case by case. $>95 \%$.

2.5 Positive clinical predictive value (life time risk to develop the disease if the test is positive) ${ }^{20,21}$ Life-time risk to develop the disease when patient is exposed to 'trigger' anesthetics is $>75 \%$.

2.6 Negative clinical predictive value (probability not to develop the disease if the test is negative) ${ }^{20,21}$ Assume an increased risk based on family history for a non-affected person. Allelic and locus heterogeneity may need to be considered.

Index case in that family had been tested:

$\sim 90 \%$.

Index case in that family had not been tested: $\sim 15 \%$.

\footnotetext{
1Department of Medical Education and Clinical Research, Saint Barnabas Medical Center, Livingston, NJ, USA; '2Department of Anesthesiology and Intensive Care Medicine, University Hospital, Leipzig, Germany; ${ }^{3}$ HELIOS Kliniken Leipziger Land, Borna, Germany

*Correspondence: Dr H Rosenberg, Saint Barnabas Medical Center, Department of Medical Education and Clinical Research; 94 Old Short Hills Road, Livingston, NJ 07024, USA. Tel: +1 973322 5777; Fax: +1 973322 8720; E-mail: hrosenberg@sbhcs.com
} 


\section{CLINICAL UTILITY}

3.1 (Differential) diagnosis: The tested person is clinically affected Besides MH, a number of RYR1 mutations have been described to be associated with rare congenital myopathies. These include myopathies with cores (central core disease (CCD): MIM \#11700; specific forms of multiminicore disease (MmD): MIM\#255320) or central nuclei (centronuclear myopathy: MIM\#160150) that are associated with a wide range of phenotypes. CCD is closely linked with $\mathrm{MH}$, as both disorders share the same gene locus. In the other congenital myopathies, RYR1 mutations are rather an exception, but the $\mathrm{MH}$ risk must also be considered high until more information becomes available. $^{22-27}$

In contrast to this, there are disorders or syndromes that are very similar to classical $\mathrm{MH}$, for example, serotonin syndrome or neuroleptic malignant syndrome. Other myopathies, such as Duchenne or Becker's muscular dystrophy, may induce 'MH-like' symptoms under general anesthesia due to other pathophysiological pathways than for $\mathrm{MH} .{ }^{19}$

\subsubsection{Can a diagnosis be made other than through a genetic test? ${ }^{17-19,28,29}$}

\begin{tabular}{ll}
\hline No $\quad \square$ (continue with 3.1.4) \\
Yes $\quad \begin{array}{ll}\text { Clinically } \\
\text { Imaging }\end{array}$ \\
Endoscopy & $\square$ \\
Biochemistry & $\square$ \\
Electrophysiology & $\square$ \\
Other (please & Q In vitro contracture test (also called caffeine \\
describe) & halothane contracture test): contracture of muscle \\
& fascicles from a fresh muscle biopsy (weight $\sim 200 \mathrm{mg}$ ) \\
& following exposure to halothane and caffeine.
\end{tabular}

3.1.2 Describe the burden of alternative diagnostic methods to the patient?

Patients need surgery (open muscle biopsy). Contracture test must be performed within few hours of harvest. IVCT/CHCT can be performed only in special MH centers. ${ }^{1,2}$

3.1.3 How is the cost effectiveness of alternative diagnostic methods to be judged?

Cost for muscle biopsy and IVCT: about $€ 2000$ in Europe. In the USA, the test is the CHCT version with a cost of about $\$ 6000$.

\subsubsection{Will disease management be influenced by the result of a} genetic test?

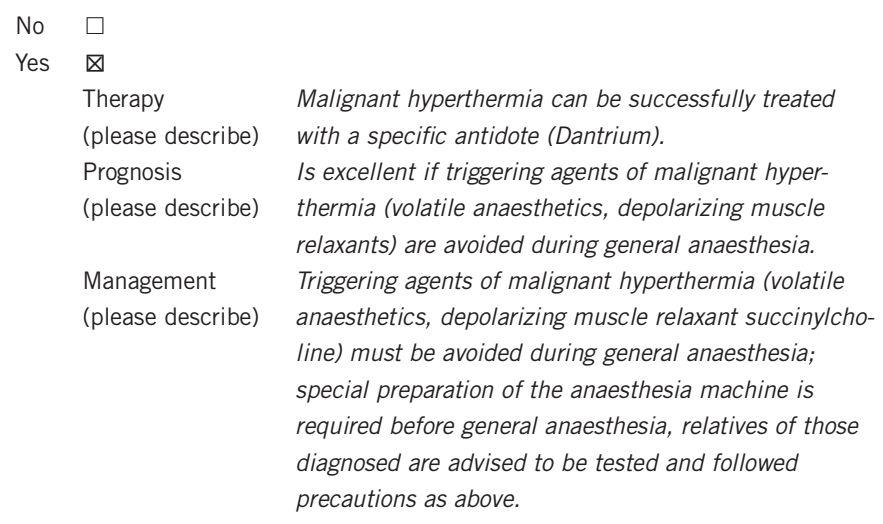

European Journal of Human Genetics
3.2 Predictive setting: The tested person is clinically unaffected but carries an increased risk based on family history

$\mathrm{MH}$ predisposed persons are clinically unaffected until exposed to $\mathrm{MH}$ trigger agents.

Only patients who are tested $\mathrm{MH}$ positive need a special anaesthetic management during surgery. MH negative tested persons can be handled like the 'normal' patients; regardless of the family history.

\subsubsection{Will the result of a genetic test influence lifestyle and prevention $?^{1,2,5}$}

Yes.

If the test result is positive (please describe):

The patient gets an anesthesia-warning card to alert the anesthesiologist to problems during anesthesia. The card should always be carried by the holder. Extreme caution when exercising in hot environment and with extreme exercise.

If the test result is negative (please describe):

For clinical reasons of safety the patient needs to undergo a negative confirmation test (muscle biopsy, halothane/caffeine provocation test).

3.2.2 Which options in view of lifestyle and prevention does a person at-risk have if no genetic test has been done (please describe)?

Person should be alternatively tested with the IVCT/CHCT (muscle biopsy) to determine the $\mathrm{MH}$ risk. Otherwise the patient should consider himself at risk for $\mathrm{MH}$.

3.3 Genetic risk assessment in family members of a diseased person $50 \%$.

3.3.1 Does the result of a genetic test resolve the genetic situation in that family?

Yes, if a mutation is found. If the index patient does not have a mutation, MH susceptibility is still a possibility because of heterogeneity.

3.3.2 Can a genetic test in the index patient save genetic or other tests in family members?

Yes.

3.3.3 Does a positive genetic test result in the index patient enable a predictive test in a family member? Yes.

\subsection{Prenatal diagnosis}

3.4.1 Does a positive genetic test result in the index patient enable a prenatal diagnostic?

Prenatal diagnosis is not yet approved solely for $\mathrm{MH}$ diagnosis but would be a promising option and would make sense if the familial $\mathrm{MH}$ mutation is known. PND could increase patient safety, for example, for the newborn of $\mathrm{MH}$ positive parents ( $\mathrm{MH}$-positive mother or father, newborn is $50 \%$ at risk) under the situation of a Cesarean section. In this case $\mathrm{MH}$ triggering agents (given under general anesthesia) must be avoided even if the mother is negative.

On the other hand, prenatal diagnosis is an important option for other congenital RYR1-related disorders and if such an indication is given the search for $\mathrm{MH}$-associated mutations could be taken under consideration.

\section{IF APPLICABLE, FURTHER CONSEQUENCES OF TESTING}

Please assume that the result of a genetic test has no immediate medical consequences. Is there any evidence that a genetic test is nevertheless useful for the patient or his/her relatives? (Please describe) 
Yes. If a mutation associated with $\mathrm{CCD}$ or $\mathrm{MmD}$ is found, the patient should be followed for evidence of muscle weakness. Prenatal counseling is advised in such cases.

Family members should be treated as MH susceptible until IVCT/ CHCT test is done with a negative result.

\section{CONFLICT OF INTEREST}

The authors declare no conflict of interest.

\section{ACKNOWLEDGEMENTS}

This work was supported by the EuroGentest, an EU-FP6 supported NoE, contract number 512148 (EuroGentest Unit 3: 'Clinical genetics, community genetics and public health', Workpackage 3.2).

1 European Malignant Hyperthermia Group (EMHG), http://www.emhg.org.

2 Malignant Hyperthermia Association of the United States (MHAUS), http://www. mhaus.org.

3 McCarthy TV, Healy JM, Heffron JJ et al: Localization of the malignant hyperthermia susceptibility locus to human chromosome 19q12-13.2. Nature 1990; 343: 562-564.

4 Monnier N, Procaccio V, Stieglitz P, Lunardi J: Malignant-hyperthermia susceptibility is associated with a mutation of the alpha-1-subunit of the human dihydropyridinesensitive L-type voltage-dependent calcium-channel receptor in skeletal muscle. Am J Hum Genet 1997; 60: 1316-1325.

5 Urwyler A, Deufel T, McCarthy T, West S: Guidelines for molecular genetic detection of susceptibility to malignant hyperthermia. Br J Anaesth 2001; 86: 283-287.

6 McCarthy TV, Quane KA, Lynch PJ: Ryanodine receptor mutations in malignant hyperthermia and central core disease. Hum Mutat 2000; 15: 410-417.

7 Sambuughin N, Holley H, Muldoon S et al: Screening of the entire ryanodine receptor type 1 coding region for sequence variants associated with malignant hyperthermia susceptibility in the North American population. Anesthesiology 2005; 102: 515-521.

8 Stewart SL, Hogan K, Rosenberg H, Fletcher JE: Identification of the Arg1086His mutation in the alpha subunit of the voltage-dependent calcium channel (CACNA1S) in a North American family with malignant hyperthermia. Clin Genet 2001; 59: 178-184.

9 Ibarra MC, Wu S, Murayama $\mathrm{K}$ et al: Malignant hyperthermia in Japan: mutation screening of the entire ryanodine receptor type 1 gene coding region by direct sequencing. Anesthesiology 2006; 104: 1146-1154.

10 Rueffert H, Olthoff D, Deutrich C et al: Mutation screening in the ryanodine receptor 1 gene (RYR1) in patients susceptible to malignant hyperthermia who show definite IVCT results: identification of three novel mutations. Acta Anaesthesiol Scand 2002; 46 692-698.
11 Levano S, Vukcevic M, Singer M et al: Increasing the number of diagnostic mutations in malignant hyperthermia. Hum Mutat 2009; 30: 590-598.

12 Girard T, Litman RS: Molecular genetic testing to diagnose malignant hyperthermia susceptibility. J Clin Anesth 2008; 20: 161-163.

13 Stowell KM, Pollock N: DNA analysis and malignant hyperthermia susceptibility. Anaesth Intensive Care 2008; 36: 305-307.

14 Monnier N, Krivosic-Horber R, Payen JF et al: Presence of two different genetic traits in malignant hyperthermia families: implication for genetic analysis, diagnosis, and incidence of malignant hyperthermia susceptibility. Anesthesiology 2002; 97: 1067-1074.

15 Ording H: Incidence of malignant hyperthermia in Denmark. Anesth Analg 1985; 64: 700-704.

16 Brady JE, Sun LS, Rosenberg H, Li G: Prevalence of malignant hyperthermia due to anesthesia in New York State, 2001-2005. Anesth Analg 2009; 109: $1162-1166$.

17 Ording $\mathrm{H}$, Brancadoro V, Cozzolino $\mathrm{S}$ et al: In vitro contracture test for diagnosis of malignant hyperthermia following the protocol of the European $\mathrm{MH}$ Group: results of testing patients surviving fulminant $\mathrm{MH}$ and unrelated low-risk subjects. The European Malignant Hyperthermia Group. Acta Anaesthesiol Scand 1997; 41: 955-966.

18 Larach MG, Localio AR, Allen GC et al: A clinical grading scale to predict malignant hyperthermia susceptibility. Anesthesiology 1994; 80: 771-779.

19 Wappler F: Anesthesia for patients with a history of malignant hyperthermia. Curr Opin Anaesthesiol 2010; 23: 417-422.

20 Rosenberg H, Davis M, James D et al: Malignant hyperthermia. Orphanet J Rare Dis 2007; $2: 21$.

21 Litman RS, Rosenberg $\mathrm{H}$ : Malignant hyperthermia: update on susceptibility testing. JAMA 2005; 293: 2918-2924.

22 Zhou H, Lillis S, Loy RE et al: Multi-minicore disease and atypical periodic paralysis associated with novel mutations in the skeletal muscle ryanodine receptor (RYR1) gene. Neuromuscul Disord 2010; 20: 166-173.

23 Wilmshurst JM, Lillis S, Zhou $\mathrm{H}$ et al: RYR1 mutations are a common cause of congenital myopathies with central nuclei. Ann Neurol 2010; 68: 717-726.

24 Treves S, Jungbluth H, Muntoni F, Zorzato F: Congenital muscle disorders with cores: the ryanodine receptor calcium channel paradigm. Curr Opin Pharmacol 2008; 8: 319-326.

25 Robinson RL, Brooks C, Brown SL et al: RYR1 mutations causing central core disease are associated with more severe malignant hyperthermia in vitro contracture test phenotypes. Hum Mutat 2002; 20: 88-97.

26 Carpenter D, Robinson RL, Quinnell RJ et al: Genetic variation in RYR1and malignant hyperthermia phenotypes. Br J Anaesth 2009; 103: 538-548.

27 Ducreux S, Zorzato F, Ferreiro A et al: Functional properties of ryanodine receptors carrying three amino acid substitutions identified in patients affected by multiminicore disease and central core disease, expressed in immortalized lymphocytes. Biochem J 2006; 395: 259-266.

28 Larach MG: Standardization of the caffeine halothane muscle contracture test. North American Malignant Hyperthermia Group. Anesth Analg 1989; 69: 511-515.

29 Rosenberg H, Dirksen RA, Sambuughin N: Malignant hyperthermia susceptibility; in Baskin P, Pagan R (ed): GeneReviews, http://www.genetests.org. 